\title{
ENHANCING BRAND AWARENESS VIA HALAL BRAND PERSONALITY
}

\author{
AL AMIRUL EIMER RAMDZAN ALI ${ }^{1 *}$, KHAIRIL AZWAR RAZALI $^{2}$, ABDUL KADIR $^{*}$ \\ OTHMAN $^{3}$ \\ ${ }^{1 \& 2}$ Kulliyyah of Languages and Management, International Islamic University Malaysia (IIUM), Jalan \\ Gombak, 53100 Kuala Lumpur, Malaysia. \\ ${ }^{3}$ Institute of Business Excellence (IBE), 42300 UiTM Cawangan Selangor, Selangor Darul Ehsan, \\ Malaysia. \\ ${ }^{3}$ Faculty of Business Management, 42300 UiTM Cawangan Selangor, Selangor Darul Ehsan, Malaysia. \\ *Corresponding author: dral@iium.edu.my
}

(Received: $20^{\text {th. }}$ Apr. 2020, Accepted: $23^{\text {rd }}$ Sept. 2020, Published on-line: 15 $5^{\text {th }}$ Jan. 2021)

\begin{abstract}
This paper develops the concept of the halal brand personally dimensions introduced by Ahmad which consists of (i) purity, (ii) excitement, (iii) sophistication, (iv) safety and (iv) righteousness on brand awareness. The concept of halal brand personality is vital for service providers to create an awareness about their products and services in the consumers' mind as this could be the catalyst for service providers to achieve sustainable competitive advantage (SCA). This is because the five factors that contribute to the halal brand personality are being regarded to be an assurance for halal products and services. It symbolizes the value that are not just for Muslims, but for non-Muslims as well. The concept of halal brand personality will assist the marketers, service providers to convince the customers that the products offered are safe and high in quality.
\end{abstract}

KEYWORDS: Halal brand personality; Brand awareness

\section{INTRODUCTION}

The concept of brand awareness has been regarded as one of the important indicators of consumers' knowledge about a specific brand, products, services, the strength of a brand's presence in the consumer's mind and also the capability of the consumers to retrieve these knowledge from their memory, (O'guinn, Allen \& Semenik, 2003). It is the probability that the consumers will easily recall and recognize the presence and availability of a company's products and services. In the establishment of brand awareness, companies or service providers have ensure that the consumers must first get to know the name of the company, then the name will form the consumers' view on the image and the purpose of the company and its activities, (Berry, 2000). When consumers choose and evaluate specific products and services, brand 
awareness plays a vital role. For small and new businesses, brand awareness is crucial. Wellknown brands, services will attain consumers' confidence in which, it allows consumers to take advantage of the known brands or services rendered by the company, (Keller, 2003). One of the advantages of a well-known brand is that it mitigates the risk for consumers to think or perhaps shift to another brand. From the view of a long-term business, brand awareness will create a stable demand for service from the consumer side, which will assist the service providers to alleviate their market share. Hence, these benefits will add value to the company's revenue which may be the main goal of creating a concrete brand awareness. In order to achieve the true goal of brand awareness, companies employ a wide range of brand management strategies such as brand equity, brand personality and others as their main focus to elevate their position in the market and to create loyalty from the consumers, (Rockute et al., 2018).

According to Lada et al. (2009), most of the businesses are constantly fighting to secure maximum capital market share. As for example, McDonald and Nestle have invested substantially to capture an extensive share of food and beverages' market. With the emerging of competitive market, each product type offers many different brands with the objective to attract more customers, (Aziz \& Vui, 2012). The concept of as the central Islamic marketing asset has the capability to enhance the brand entity of products and services offered by companies. Considering this, halal brand is a safe place to mitigate the uncertainty associated with product purchase. It also acts as a catalyst of establishing a strong relationship between the companies and consumers, (Borzooei \& Asgari, 2013). There are few reasons for integrating halal into the concept of branding. First and foremost, halal is able to go beyond just the indication of a pure and healthy products and services. Secondly, the concept of halal branding will assist the companies to venture into new markets by inculcating value to its products and services in the current competitive market. Since Malaysia is heading towards becoming the global halal hub, service providers have to ensure that the products offered are based on the Islamic Shari'ah and via strong halal branding management, it will assist the service providers to be more competitive in the market, (Ahmad, 2015). This study will examine and enhance the model of halal brand personality in developing an exceptional brand personality for halal products and services.

In today's era, consumers are being exposed to different kinds of similar products, offered by different service providers. Because of this, some of the consumers are making their own rules to purchase only those brands which are famous in the market. This is where the concept of brand awareness is very important, (Nidumolu et al., 2009). Companies need to constantly create the awareness of their brand in the mind of the consumer because, if there is no brand awareness, no communication or perhaps the transaction will occur and it is difficult for the companies to survive with less consumers, (Malik et al., 2013). There are also less research focusing on halal branding. The current study on halal only focuses on halal market condition, (Alserhan, 2010), halal supply chain management, (Tieman, 2011) and halal certification, (Shafie \& Othman, 2006). Existing studies have also investigated the concept of halal as a separate phenomenon and not as part of brand management, (Wilson \& Liu, 2010). These studies are meant to investigate the concept of halal branding on purchase intention, not the awareness of the brand. 


\section{LITERATURE REVIEW}

\subsection{Brand Awareness}

Brand awareness can be best defined as the ability of a consumer to recognize and recall a specific brands or services in multiple situations, (Aaker, 1996). This concept discusses two (2) main aspects namely brand recognition and brand recall. Brand recognition is a situation where the consumers have the ability to identify a specific brand when there is a brand cue, (Chi et al., 2009). As for brand recall, it is the ability to recall a brand name correctly whenever consumers see a product category. According to Hoeffler and Keller (2002), brand awareness can be differentiated into two (2) different concepts which are 'depth' and 'width'. Depth is how to make consumers to identify and recall a specific brand easily and width on the other had is when consumers purchase a product, a brand name will come across their minds at once. Higher brand awareness is the result of the combination between brand depth and brand width. Furthermore, brand awareness plays a crucial role in determining the purchase intention of the consumers because they tend to purchase a product that is well-known and familiar, (Keller, 1993 and Macdonald \& Sharp, 2000). In this view, brand awareness will assist the consumers to recognize a brand from a product's category and once the consumers have recognized, they will procced to make the purchasing decision. Additionally, the concept of brand awareness plays a crucial role in building a brand in the consumers' mind with the hope that the consumers will make purchasing decision based on knowledge, experience, or awareness on certain brands. Due to this, consumers may purchase the products repeatedly as they are assured of its quality. Thus, brand awareness, is related to brand loyalty, (Alkhawaldeh et al., 2017).

\subsubsection{Brand Personality and the Conceptualization of Halal Brand Personality}

The concept of brand personality was first coined by Aaker (1997) in which brand personality is defined as the set of human characteristics that is linked to a brand. The five (5) dimensions of brand personality are Sincerity, Excitement, Competence, Sophistication and Ruggedness. Furthermore, the concept of brand personality measures an individual's behavior, beliefs, attitude, and demographic characteristic of the five-dimensional model, which is name the Big Five factors of brand personality, (Caprara et al., 2001). Malaysia is currently active in becoming the halal hub for the Southeast Asia region and one of the vital steps in realizing this vision is to elevate on the standards for halal food procedure, leveraging on MS 1500:2004 from the Department of Standards, Malaysia, (Ahmad, 2015). In view of this, the term halal is added in which the human personality trait can be linked with the concept of halalan toyyibam. The concept of halal brand personality can be further explained in five (5) dimensions namely Purity, Excitement, Righteousness, Safety and Sophistication. These five dimensions was based on the result of the structured interview with seven halal certification experts of JAKIM, (Ahmad, 2015).

\subsection{Purity}

Ahmad (2015) stated that, human beings are born into this world in the state of purity. Hence, looking back at the concept of their nature (fitrah), it is recommended for Muslims to purchase products that are halal certified. In this view, service producers have to ensure that the 
products that they sell are free from any forbidden (haram) ingredients, (Zainudin, Hasan \& Othman, 2019). Furthermore, it is very crucial for service providers to ensure that the resources and the distribution channels are pure and free from illegal components that might jeopardize the purity of the products and services, (Shaari \& Arifin, 2010). The concept of purity is deemed crucial because it allows consumers to feel assured about the products that they are consuming as it is not questionable (shubhah). It is also linked to the concept of sincerity that the brands are showcasing to their customers and it relies heavily on the concept of morality (Walker, 1978). Ahmad (2015) further supported that sincere brands are considered pure and will create brand awareness amongst consumers.

\subsection{Excitement}

The concept of excitement is best defined as an excited state or condition, and it is frequently linked to the concepts of sociability, energy and activities that are dynamic, (Ahmad, 2015). In view of this, Sung and Kim (2010) stated that excitement has a close connection with consumer's emotional responses. Brands that successfully make the consumers feel excited will elevate the consumers' commitment. Brands that are exciting will showcase the elements of contemporary and up to date which will be the main indicator to capture the attention and awareness of the consumers and will have a positive influence on consumers' attitude. Consumers will also feel excited if the brands offered are high in quality and this will lead to consumer's satisfaction and will influence their purchasing decision, (Ahmad, 2015).

\subsection{Safety}

In any business to customer (B2C) nature of business, service providers are expected to understand consumers' true needs, wants and to ensure that consumers feel safe while consuming any product, (Kim \& Chung, 2011). According to Man and Yahya (2014), safety can be best defined as the consumers' freedom from any damage, danger and injury from the consumption of the products produced by service providers. Rajagopal et al. (2011), further supported that the concept of safety in halal brand personality must adhere with the Shari'ah law and good judgement. Ahmad (2015) stated that this concept is also liked to the consumers' assurance and dependability of the brands to meet the consumers' needs by having the ability of the brand to project the safety attributes of the products and services. Hence, if the consumers are feeling safe with products and services, they are more likely to develop positive purchasing decision towards the brand, (Lau \& Lee, 1999). Lastly, this concept would be able to act as a platform for an effective marketing and corporate communication strategies.

\subsection{Sophistication}

According to Okazaki (2006), sophistication is the process or change of an outcome from simple or basic to the well-informed or personalized products and services. Authorities have to ensure that the halal industry comply to the halal brand personality requirements in coming out with halal products and services, especially to those service providers who would like to promote their halal products and services. According to Ahmad (2015), consumers and service providers have to work together in the sense that consumers are required to give feedback and from the feedback itself, service providers have to make some changes according to the 
requirements by the consumers. Service providers are expected to assist their consumers to fully understand about specific products and services. In this view, service providers are regarded as being responsible for providing insights to consumers with respect to all the service delivery process such as the sources, the material involved, handling processes and up to presenting the products to patrons. Since consumers are being exposed to same products and services but from different service providers, it is very important if the products can be tailor-made or personalized as this would allow the service providers to stay competitive in the market.

\subsection{Righteousness}

The last concept in halal brand personality is righteousness. Ahmad (2015) stated that righteousness is in line with the virtue or morality form the perspective of Islam. Halstead (2004) further supported where this concept is viewed as the submission, surrender and obedience to Islam. In marketing and branding, the concept of righteousness plays a very crucial role in persuading the consumers' purchasing decision in which their behavior and attitude are bound by their faith. This is because, this concept offers psychological comforts to the consumers who have been accepting the concept of halal in any products and services. Aris (2012) and Khairudin (2013) stated that righteousness will have a positive influence on the consumer's behavior and attitude. Li (2018), mentioned that the heart in any religion is loyalty and the concept of righteousness is a multi-dimensional construct that allows the consumers to stay loyal to a specific brand.

\subsection{The Relationship Between Purity and Brand Awareness}

The concept of purity in halal brand personality can be linked to the sincerity that the service provider and brand provide to their customers and it relies heavily on the concept of morality. The concept of sincerity usually associated to brand awareness as it is linked to the concept of fairness. Consumers are to be made aware and tend to stay loyal to the brand which they perceive to be fair to them, (Bowman \& Narayandas, 2001). Aaker et al., (2004) further supported that sincerity of the brand will be the main indicator in building consumer-brand relationship. Since consumers are being exposed to numerous brands and services, consumers tend to stay with the brands that are being sincere and sincerity here can be in many forms such as treatment of the personnel, price offered and many more. Sincere brands are also perceived as having high moral values in which it will create brand awareness and brand loyalty amongst consumers (Maehle et al., 2011).

\subsubsection{The Relationship Between Excitement and Brand Awareness}

The concept of excitement in halal brand personality is linked to the ability of the service providers to make the consumers feel excited about their brands. Ahmad (2015) suggested that the construct of excitement in halal brand personality should cover exciting, cool, awesome, imaginative, and unique features. In this view, if the brands are unique in their own way, it will have a positive influence on consumers' attitude towards the brand in which it will showcase that there will be a significant relationship between excitement and brand awareness. Brands that have unique features will encourage consumers to aware of the brand because it shows that there is a personalization of the brands for the consumers. Chung and Park (2017) 
stated that brands with high personalization will create a strong image of the brand in the mind of the consumers and it will also create brand loyalty. In this view also, Ahmad (2015) stated that excitement will contribute to consumer satisfaction and once consumers are satisfied, they will tend to repurchase the products and will create word of mouth to other consumers which will result in more brand awareness especially on prospect consumers.

\subsubsection{The Relationship Between Safety and Brand Awareness}

The safety's dimension in halal brand personality is linked to the amount of trust that the consumers have towards the brand. Boon and Holmes (1991) stated that trust is a state of confident, positive attitude about an uncertain situation. Via this definition, trust can be further redefined as the consumers' assurance on the safety of using and believing in any product that they are consuming and this definition is in line with the concept of safety in halal brand personally which was proposed by Ahmad (2015). Consumers' trust on the safety of the product will first create a favorable brand awareness then will continue in building long-term relationship with the brand, (Sarpong, 2014). In view of this, if the consumers feel safe with the products and services, they tend to create a positive purchasing behavior for a long period of time, (Lassoued \& Hobbs, 2015). Furthermore, consumer's assurance on the safety aspect of products and services will create a high value relationship between the consumers and the brand. Once the consumers are aware of the brand, according to Ramaseshan and Stein (2014), it will result in both behavioral and attitudinal loyalty.

\subsubsection{The Relationship Between Sophistication and Brand Awareness}

The concept of sophistication is closely related to corporate reputation, (Raithel \& Schwaiger, 2015). Corporate reputation is the ability of the companies to rendered valued results to their stakeholders. Based on this definition, corporate reputation is also the ability of the companies to provide excellent performance via their products and services and in order to elevate their corporate reputation, they must be able to provide differentiation to their consumers. The ability to provide differentiation to the consumers is one of the elements of sophistication in halal brand personality, (Ahmad, 2015). The reputation of the brand is crucial for two reasons; first, it helps to create a strong brand awareness which will lead to consumer decision-making process and secondly, it will assist the service providers to create differentiation in the market, allowing consumers to stay loyal for a specific period of time, (Dijkmans et al., 2015). Lastly, positive brand reputation will result in more investment from potential investors, employees who are highly skilled and would be able to stay competitive in the market.

\subsubsection{The Relationship Between Righteousness and Brand Awareness}

Dalmoro et al., (2015) stated that consumers will decide their preferred brand via their cultural experiences. The context of religiosity is best defined as the integration of religion in an individual life in which it will influence consumers' cultural experience. Furthermore, religiosity is a multi-construct that can create brand awareness and loyalty amongst the consumers, (Minton, 2018). Consumers who are highly religious also showcase a strong sense of awareness and loyalty towards their belief system. In regard to the stereotype of strong believer, the quality of awareness can be extended beyond the religion concept itself. These types of 
consumers appeared to have brand awareness and brand loyalty and these two are not limited to their beliefs and behaviors. In another view, righteousness or religiosity might be a catalyst in building a strong relationship between the consumers and the brand. This is also further supported by Djupe and Gilbert (2002) where righteousness will act as a form or brand awareness and once the consumers are aware of the brand, they tend to purchase that specific product without any hesitation.

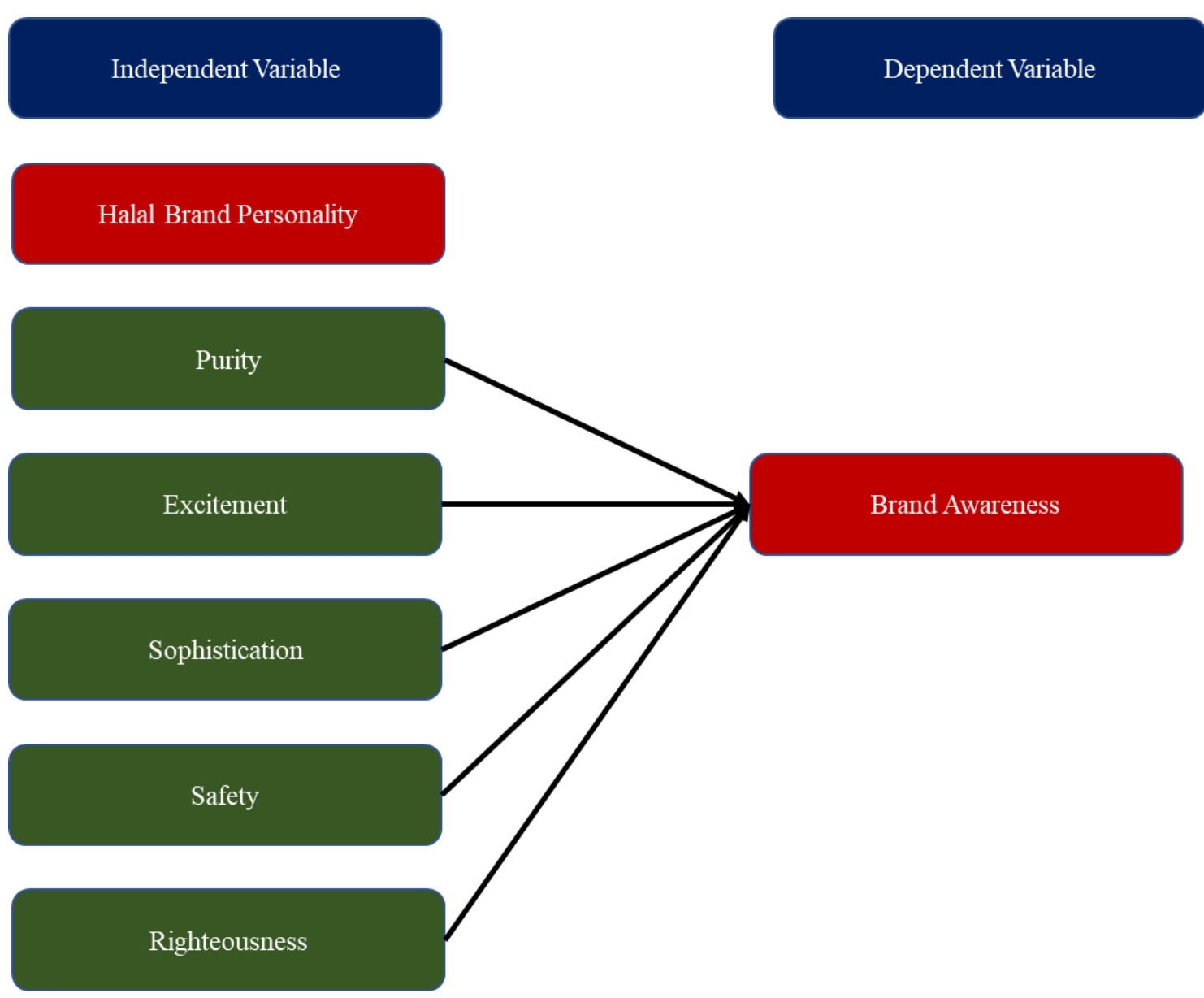

Fig. 1: Halal brand personality and brand awareness framework.

\section{CONCLUSION}

The concept of halal brand personality was based on the original concept of brand personality which was first introduced by Aaker (1997). The purpose of this study was to explore the relationship between halal brand personality on brand awareness. As product markets continue to grow rapidly, it is crucial to both marketing and branding personnel to capture the opportunity to optimize the available resources to work on halal brand personality concept. The dimensions of halal brand personality were being introduced in this conceptual paper which will provide more insights on the current body of knowledge especially in the field of marketing and branding. The proposed framework of halal brand personality on brand awareness might be 
useful for scholars as they would be able to link the concept of halal with branding, halal marketers and practitioners as they can leverage on this strategy to attract new customers and retain their existing customers. Globally, it is the fact that even the non-Muslims are now looking for halal products and services, hence, this is the best time for service providers to cater to these needs of the consumers.

\section{REFERENCES}

[1] Aaker, D.A. (1996). Measuring brand equity across products and markets. California Management Review, 38(3), 102.

[2] Aaker, J., Fournier, S., \& Brasel, S.A. (2004). When good brands do bad. Journal of Consumer Research, 31(1), 1-16.

[3] Aaker, J.L. (1997). Index of brand personality. Journal of Marketing Research, 34(3), 347.

[4] Ahmad, M. F. (2015). Antecedents of halal brand personality. Journal of Islamic Marketing, 6(2), 209-223.

[5] Alkhawaldeh, A.M., Salaymeh, M.A., Alshare, F., \& Eneizan, B.M. (2017). The Effect of Brand Awareness on Brand Loyalty: Mediating Role of Brand Commitment. European Journal of Business and Management, 9(36), 38-47.

[6] Alserhan, B. A. (2010). Islamic branding: A conceptualization of related terms. Brand Management, 18(1), 34-49.

[7] Aris, A.T. (2012). Muslim attitude and awareness towards Istihalah. Journal of Islamic Marketing, 3(3), 244-254.

[8] Aziz, Y. A., \& Vui, C. N. (2012). The Role of Halal Awareness and Halal Certification in Influencing non-Muslims' Purchase Intention. Paper presented at the 3rd International Conference on Business and Economic Research, Indonesia.

[9] Berry, L. L. (2000). Cultivating Service Brand Equity. Academy of Marketing Science, 28, 128-137.

[10] Boon, S.D., \& Holmes, J.G. (1991). The dynamics of interpersonal trust: Resolving uncertainty in the face of risk, Cambridge University Press, Cambridge.

[11] Borzooei, M., \& Asgari, M. (2103). The Halal brand personality and its effect on purchase intention. Interdisciplinary Journal of Cotemporary Research in Business, 5(3), 481-491.

[12] Bowman, D., \& Narayandas, D. (2001). Managing customer-initiated contacts with manufacturers: The impact on share of category requirements and word-of-mouth behaviour. Journal of Marketing Research, 38(3), 281-297.

[13] Caprara, G. V., Barbaranelli, C. \& Guido, G. (2001). Brand personality: How to make the metaphor fit? Journal of Economic Psychology, 22(3), 377-395.

[14] Chi, H.K., Yeh, H.R., \& Yang, Y. T. (2009). The impact of brand awareness on consumer purchase intention: The mediating effect of perceived quality and brand loyalty. Journal of International Management Studies, 4(1), 135-144.

[15] Chung, S., \& Park, J. (2017). The influence of brand personality and relative brand identification on brand loyalty in the European mobile phone market. Canadian Journal of Administrative Sciences, 34(1), 47-62. 
[16] Dalmoro, M., Pinto, D.C., Borges, A., \& Nique, W. M. (2015). Global brands in emerging markets: The cultural antecedents of global brand preference. Journal of Brand Management, 22(9), 721-736.

[17] Dijkmans, C., Kerkhof, P., \& Beukeboom, C.J. (2015). A stage to engage: Social media use and corporate reputation. Tourism Management, 47, 58-67.

[18] Djupe,P.A., \& Gilbert, C.P.(2002). The political voice of clergy. The Journal of Politics, 64(2), 596-609.

[19] Halstead, M. (2004). An Islamic concept of education. Comparative Education, 40(4), 517-529.

[20] Hoeffler, S., \& Keller, K.L. (2002). Building brand equity through corporate social marketing. Journal of Public Policy and Marketing, 21(1), 78-89.

[21] Keller, K. L. (2003). Brand synthesis: The multi dimensionality of brand knowledge. Journal of Consumer Research, 29, 595-600.

[22] Keller, K.L. (1993). Conceptualizing, measuring, and managing customer-based brand equity. Journal of Marketing, 57(1), 1-22.

[23] Khairudin, S. (2013), Halalan thayyiban: Amalan rukhsah dalam pemakanan, 1st ed., Telaga Biru Sdn. Bhd, Kuala Lumpur.

[24] Kim, H.Y. \& Chung, J.E. (2011). Consumer purchase intention for organic personal care products. Journal of Consumer Marketing, 28(1), 40-47.

[25] Lada, S., Tanakinjal, G. H., \& Amin, H. (2009). Predicting intention to choose halal products using theory of reasoned action. International Journal of Islamic and Middle Eastern Finance and Management, 2(1), 66-76.

[26] Lassoued, R., \& Hobbs, J.E. (2015). Consumer confidence in credence attributes: The role of brand trust. Food Policy, 52, 99-107.

[27] Lau, G.T., \& Lee, S.H. (1999). Consumers' trust in a brand and the link to brand loyalty. Journal of Market-Focused Management, 4(4), 341-370.

[28] Li, Y. (2018). The influence of changes of Islam and politics relations in $20^{\text {th }}$ century on the strategy of belt and road. International Journal of Social Science Studies, 6(2), 123127.

[29] Macdonald, E.K., \& Sharp, B.M. (2000). Brand awareness effects on consumer decision making for a common, repeat purchase product: A replication. Journal of Business Research, 48, 5-15.

[30] Maehle, N., Otnes, C., \& Supphellen, M. (2011). Consumers' perceptions of the dimensions of brand personality. Journal of Consumer Behaviour, 10(5), 290-303.

[31] Malik, M.E., Ghafoor, M.M., Iqbal, H. K., Riaz, U., Hassan, N.U., Mustafa, M., \& Shahbaz, S. (2013). Importance of brand awareness and brand loyalty in assessing purchase intentions of consumer. International Journal of Business and Social Science, 4(5), 167-171.

[32] Minton, E.A. (2018). Affective and cognitive religiosity: Influences on consumer reactance and self-control. Journal of Consumer Behaviour, 17(2), 175-186.

[33] Nidumolu, R., Prahalad, C.K., \& Rangaswami, M.R. (2009). Why sustainability is now the key driver of innovation. Harvard Business Review. Retrieved on April 10, 2020 from : https://hbr.org/2009/09/why-sustainability-is-now-the-key-driver-of-innovation

[34] O'Guinn, T. C., Allen, C. T., \& Semenik, R. J. (2003). Advertising and Integrated Brand Promotion (3rd Edition). USA: South Western. 
[35] Okazaki, S. (2006). Excitement or sophistication? A preliminary exploration of online brand personality. International Marketing Review, 23(3), 279-303.

[36] Raithel, S., \& Schwaiger, M. (2015). The effects of corporate reputation perceptions of the general public on shareholder value. Strategic Management Journal, 36(6), 945-956.

[37] Rajagopal, S., Ramanan, S., \& Satapathy, S. (2011). Halal certification: implication for marketer in UAE. Journal of Islamic Marketing, 2(2), 138-153.

[38] Ramaseshan,B., \& Stein,A. (2014). Connecting the dots between brand experience and brand loyalty: The mediating role of brand personality and brand relationships. Journal of Brand Management, 21(7), 664-683.

[39] Rockute, K., Minelgaite, I., Zailskaite-Jakste, L., \& Damasevicius, R. (2018). Brand Awareness in the Context of Mistrust: The Case Study of an Employment Agency. Sustainability, 10(3), 1-13.

[40] Sarpong, S. (2014). Traceability and supply chain complexity: confronting the issues and concerns. European Business Review, 26(3), 271-284.

[41] Shaari, J. A. N., \& Arifin, N. S. B. M. (2010). Dimension of halal purchase intention: A preliminary study. International Review of Business Research Papers, 6(4), 444-456.

[42] Shafie, S., \& Othman, N. (2006). Halal Certification: an international marketing issues and challenges. Journal of Marketing Research, (15), 565-575.

[43] Sung, Y., \& Kim, J. (2010). Effects of brand personality on brand trust and brand affect. Psychology and Marketing, 27(7), 639-661.

[44] Tieman, M. (2011). The application of Halal in supply chain management: in-depth interviews. Journal of Islamic Marketing, 2(2), 186-195.

[45] Walker, A. D. M. (1978). The ideal of sincerity. Mind, 87(348), 481-497.

[46] Wilson, J. A. J., \& Liu, J. (2010). Shaping the Halal into a brand? Journal of Islamic Marketing, 1(2), 107-123.

[47] Zainudin, M.I., Hasan, F., \& Othman, A.K. (2019). Halal brand personality and brand loyalty among millennial modest fashion consumers in Malaysia. Journal of Islamic Marketing, ahead-of-print. 10.1108/JIMA-10-2018-0187. 